\title{
Phase transitions in biodegradable films based on blends of gelatin and poly (vinyl alcohol)
}

\author{
Transições de fase em filmes biodegradáveis à base de misturas de gelatina e poli (vinil álcool)
}

\author{
Paulo José do Amaral SOBRAL ${ }^{1 \star}$, Rosemary Aparecida de CARVALHO ${ }^{1}$, Izabel Cristina Freitas MORAES ${ }^{1}$, \\ Ana Mônica Quinta Barbosa BITTANTE ${ }^{1}$, Ednelí Soraya MONTERREY-QUINTERO ${ }^{1}$
}

\begin{abstract}
The aim of this work was to study the effect of the hydrolysis degree $(\mathrm{HD})$ and the concentration $\left(\mathrm{C}_{\mathrm{PVA}}\right)$ of two types of poly (vinyl alcohol) (PVA) and the effect of the type and the concentration of plasticizers on the phase properties of biodegradable films based on blends of gelatin and PVA, using a response-surface methodology. The films were made by casting and the studied properties were their glass (Tg) and melting (Tm) transition temperatures, which were determined by diferential scanning calorimetry (DSC). For the data obtained on the first scan, the fitting of the linear model was statistically significant and predictive only for the second melting temperature. In this case, the most important effect on the second Tm of the first scan was due to the HD of the PVA. In relation to the second scan, the linear model could be fit to Tg data with only two statistically significant parameters. Both the PVA and plasticizer concentrations had an important effect on Tg. Concerning the second Tm of the second scan, the linear model was fit to data with two statistically significant parameters, namely the HD and the plasticizer concentration. But, the most important effect was provoked by the HD of the PVA.
\end{abstract}

Keywords: protein; glass transition; melting; surface-response.

\section{Resumo}

O objetivo deste trabalho foi estudar o efeito do grau da hidrólise (HD) e da concentração $\left(\mathrm{C}_{\mathrm{PVA}}\right.$ ) de dois tipos de poli (vinil álcool) (PVA) e do tipo e da concentração de plastificantes nas propriedades de fases de filmes biodegradáveis à base de misturas de gelatina e PVA, usando-se metodologia de superfície de resposta. Os filmes foram feitos por casting e as propriedades estudadas foram a temperatura de transição vítrea (Tg) e a fusão (Tm), determinadas por calorimetria diferencial de varredura (DSC). Para os dados obtidos na primeira varredura, o ajuste do modelo linear foi estatisticamente significativo e preditivo somente para a segunda temperatura de fusão. Neste caso, o efeito mais importante foi devido ao HD do PVA. Com relação à segunda varredura, o modelo linear pôde ser ajustado aos dados de Tg com somente dois parâmetros significativos. As concentrações de PVA e de plastificante tiveram um efeito importante em Tg. Em relação à segunda temperatura de fusão da segunda varredura, o modelo linear foi ajustado aos dados, com dois parâmetros significativos, o HD e a concentração de plastificante. Mas, o efeito mais importante foi provocado pelo HD do PVA.

Palavras-chave: proteína; transição vítrea; fusão; superfície de resposta.

\section{Introduction}

Biodegradable films have attracted the attention of researchers and consumers due to ecological questions concerning the use of synthetic packaging. The production of these kinds of materials demands the utilization of macromolecules capable of producing a continuous thin matrix. Researches on the development and characterization of biodegradable films have been carried out using biodegradable synthetic polymers, such as poly (vinyl alcohol) (PVA) (MATSUMURA et al., 1999), biodegradable synthetic biopolymers, as poly (acid lactic) or polycaprolactone (van de VELDE; KIEKENS, 2002), or biopolymers from renewable sources, i.e. products or by-products from agriculture or from agro-industries (THARANATHAN, 2003).

Among those biopolymers, gelatin can be pointed out. It is an animal source protein, water soluble (at temperatures above sol-gel transition), product of the acid or basic hydrolysis of bone-colagen, bovine-colagen, suine-colagen or conective tissues (ARVANITOYANNIS, 2002). Gelatin can be considered different from other proteins due to a noticeable absence of internal order. At molecular level, gelatin-gel formation involves protein re-structuration, with the transition of a disordered state to a more ordered structure, and the physical properties of these gels result from the formation degree of microcrystalline junctions (ACHET; HE, 1995; ZIEGLER; FOEGEDING, 1990). Gelatin-gel dehydration - when a plasticizer agent is present - allows flexible film formation (MENEGALLI et al., 1999; ROQUES, 2008).

Therefore, gelatin has been widely used as a single biopolymer in studies on edible and/or biodegradable films (LIM; MINE; TUNG, 1999; MENEGALLI et al., 1999; SOBRAL, 1999; SOBRAL et al., 2001; CARVALHO; GROSSO, 2004; VANIN et al., 2005; THOMAZINE; CARVALHO; SOBRAL, 2005; YAKIMETS et al., 2005; BERGO; SOBRAL, 2007;

Received 11/5/2009

Accepted 17/11/2009 (004200)

${ }^{1}$ Departamento de Engenharia de Alimentos, Faculdade de Zootecnia e Engenharia de Alimentos - FZEA, Universidade de São Paulo - USP, Av. Duque de Caxias Norte, 225, CEP 13635-900, Pirassununga - SP, Brazil,E-mail: pjsobral@usp.br

*Corresponding author 
DAVANÇO; TANADA-PAIMU; GROSSO, 2007), or blended with other biopolymers (ARVANITOYANNIS et al., 1997; ARVANITOYANNIS et al., 1998a,b; XIAO et al., 2000; CAO; FU; HE, 2007; PRANOTO; LEE; PARK, 2007). On the whole, these films have limited mechanical resistance compared to synthetic films and are sensitive to the relative humidity of the air, due to the hygroscopic character of the biopolymer and plasticizers.

Several alternatives have been tested to improve the mechanical characteristics of protein-based films. Among these alternatives, the mixing of these biopolymers with the poly (vinyl alcohol) (PVA) has gained interest in the last years. The PVA is a synthetic, hydrophilic and biodegradable polymer (MATSUMURA et al., 1999) which has been used in studies on the development and characterization of films, such as PVA/wheat (DICHARRY et al., 2006), PVA/collagen hydrolysate (SARTI; SCANDOLA, 1995; ALEXY et al., 2003), and PVA/gelatin (CHIELLINI et al., 2001a,b,c; BERGO et al., 2006; MARIA et al., 2008; MENDIETA-TABOADA et al., 2008; SILVA et al., 2008; MORAES et al., 2008; CARVALHO et al., 2009), among others.

According to Pal, Banthia and Majundar (2006), the properties of PVA-based films are especially affected by the molecular weight and by the degree of hydrolysis of the PVA. Since PVA is obtained through the hydrolysis of poly (vinyl acetate), different types of PVA can be produced, depending on the degree of hydrolysis involved. Consequently, the potential to interact with other polar polymers would be expected to vary as a function of the degree of hydrolysis. Moreover, the physical properties of polymers and/or biopolymers films are strongly affected by the state of the material. The material will be hard and rigid if it is in the glass state or flexible and extendible if in the rubbery state. Thus, the knowledge of the glass transition temperature $(\mathrm{Tg})$ of films is also important, as a property defining the limit between the rubbery and glassy states (ROOS; KAREL, 1991; SLADE; LEVINE, 1991).

Very recently, Carvalho et al. (2009) used a response-surface methodology to study the effect of the hydrolysis degree (HD) and the concentrations of two types of PVA (Celvol-418, HD = 91.8\%; Celvol-350, $\mathrm{HD}=98.6 \%$ ) and of the effect of the type and the concentration of plasticizers (sorbitol or glycerol) on mechanical properties, color, opacity, moisture content and solubility in water of films based on blends of gelatin and PVA. In that study, the effect of both independent variables on the physical properties of films was explained in a statistical way. Thus, this work completes the previous one. The aim of this work was to study the effect of the hydrolysis degree and of the concentration of two types of poly (vinyl alcohol) (PVA) and of the type and the concentration of plasticizers on phase properties of biodegradable films based on blends of gelatin and PVA using a response-surface methodology. The films were made by casting and the studied properties were their phase transitions, such as glass and melting, which were determined by diferential scanning calorimetry.

\section{Materials and methods}

\subsection{Material}

The macromolecules used in film production were: pigskin gelatin $\left(\right.$ bloom $=242-248 ;$ molecular weight $\cong 5.2 \times 10^{4} \mathrm{Da}$; moisture content $=9.3 \%)$ donated by Gelita South America (Sao Paulo, Brazil), and the poly (vinyl alcohol) (PVA) with two hydrolysis degrees (HD) (Celvol-418, HD = 91.8\%; Celvol-350, $\mathrm{HD}=98.6 \%$ ) donated by Celanese (Dallas, USA). The studied plasticizers were glycerol (Synth, Brazil) and sorbitol (Nuclear, Brazil).

\subsection{Film production}

The films were produced by casting a solution of gelatin and PVA always with $2 \mathrm{~g}$ of macromolecules (gelatin + PVA). $100 \mathrm{~g}^{-1}$ film forming solution. The gelatin was hydrated for 30 minutes, and then dissolved at $55^{\circ} \mathrm{C}$ (SOBRAL et al., 2001) using a thermostatic water-bath (Marconi, Model TE 184, Brasil). The plasticizer was then added and the solution was held at $55^{\circ} \mathrm{C}$ for further 30 minutes. Besides, PVA was first homogenized in distilled water and then dissolved at $90{ }^{\circ} \mathrm{C}$ (CHIELLINI et al., 2001a) over magnetic stirring (Tecnal-TE085, Brasil). More details on this preparation can be observed in previously published works (MENDIETA-TABOADA et al., 2008; MARIA et al., 2008; CARVALHO et al., 2009).

The thickness of the films was maintained constant at $0.080 \pm 0.008 \mathrm{~mm}$, controlling the ratio of dry mass of film forming solution/support area. The thickness of the films was measured with a digital micrometer (Mytutoyo, Japan).

\subsection{Thermal properties determination}

As we were interested in studying the effect of plasticizers and/or PVA types and the concentrations on the phase properties of films, the samples were conditioned inside dessicators containing silica gel, at $22-25^{\circ} \mathrm{C}$ for at least three weeks, to try to reduce the interference of water molecules.

Samples of the films were analyzed by differential scanning calorimetry (DSC) to determine the glass and melting transition temperatures. These analyses were performed using a differential scanning calorimeter DSC TA2010 controlled by TA5000 system (TA Instruments, New Castle, DE, USA) and equipped with a cryogenic quench cooling accessory. The samples ( 10 mg) were placed in hermetically sealed aluminum TA pans and heated at $5{ }^{\circ} \mathrm{C} /$ minute (SOBRAL; MONTERREY-QUINTERO; HABITANTE, 2001; 2002) twice, always after quench cooling with liquid nitrogen. An empty pan was used as reference. The results were analyzed using the Universal Analysis V1.7F (TA Instruments) software. The glass transition temperature corresponded to the temperature where a baseline inflexion occurred, and the melting temperature was determined as the peak temperature of the endothermic event of the DSC curves.

\subsection{Experimental design}

A surface-response methodology was used to study the effect of the hydrolysis degree (HD) and of the concentration $\left(\mathrm{C}_{\mathrm{PVA}}\right)$ of two types of poly (vinyl alcohol) (PVA) and of the type $\left(\mathrm{T}_{\mathrm{p}}\right)$ and of the concentration $\left(\mathrm{C}_{\mathrm{p}}\right)$ of plasticizers on dependent variables (glass and melting transition temperatures). The levels of the independent variables were defined according to a four-factor, two-level experimental design (Table 1). A genuine replicate of the whole matrix was done to estimate the 
experimental error. A linear model (Equation 1) was used to describe the behavior of the system:

$$
Y=\beta_{0}+\Sigma \beta_{i} x_{i}+\Sigma \beta_{i j} x_{i} x_{j}
$$

Where $Y$ is the predicted response, $\beta_{0}$ is the interception coefficient, $\beta_{\mathrm{i}}$ are the linear terms, $\beta_{\mathrm{ij}}$ are the interaction terms, $\mathrm{x}_{\mathrm{i}}$ and $\mathrm{x}$ are the coded levels of the independent variables. The Student's t-test was used to verify the statistical significance of the regression coefficients. The statistical analyses (analysis of variance, regression analysis and graphical optimization) were carried out using the Statistica software (Version 7.0, Minneapolis, MN, USA).

\section{Results and discussions}

\subsection{DSC thermograms}

The DSC thermograms, in both scans for all the films, were typical of partially crystaline materials (Figure 1).
The DSC thermograms obtained during the first scan presented a glass transition ( $\mathrm{Tg}$ ) occurring between 43 and $53{ }^{\circ} \mathrm{C}$ (Table 1), related to the amorphous part of the material, followed by two endothermic peaks, related to the melting (Tm) of the crystals. Such behavior was similar to that found by Sarti and Scandola (1995), Chiellini et al. (2001b;c), Mendieta-Taboada et al. (2008) and Silva et al. (2008), for films based on PVA and collagen or gelatin. Cristalinity can also be observed on films based on both pures macromolecules. Yakimets et al. (2005) and Bergo and Sobral (2007) studied films based on pure gelatin by X-ray diffraction and verified that these films were partially crystalline, and Xiao et al. (2000) also confirmed the crystallinity of films based on PVA.

The occurrence of two endotherms in the DSC thermograms for the first scan (Figure 1) may suggest that the macromolecules were not thermodynamically miscible, therefore, emerging phase separation. The endothermic peak, visible at lower temperatures $\left(92-139^{\circ} \mathrm{C}\right)$, must be associated to the sol-gel transition of the gelatin rich fraction, while the other peak, present at higher

Table 1. Responses of thermal properties obtained from the first scan by differential scanning calorimetry.

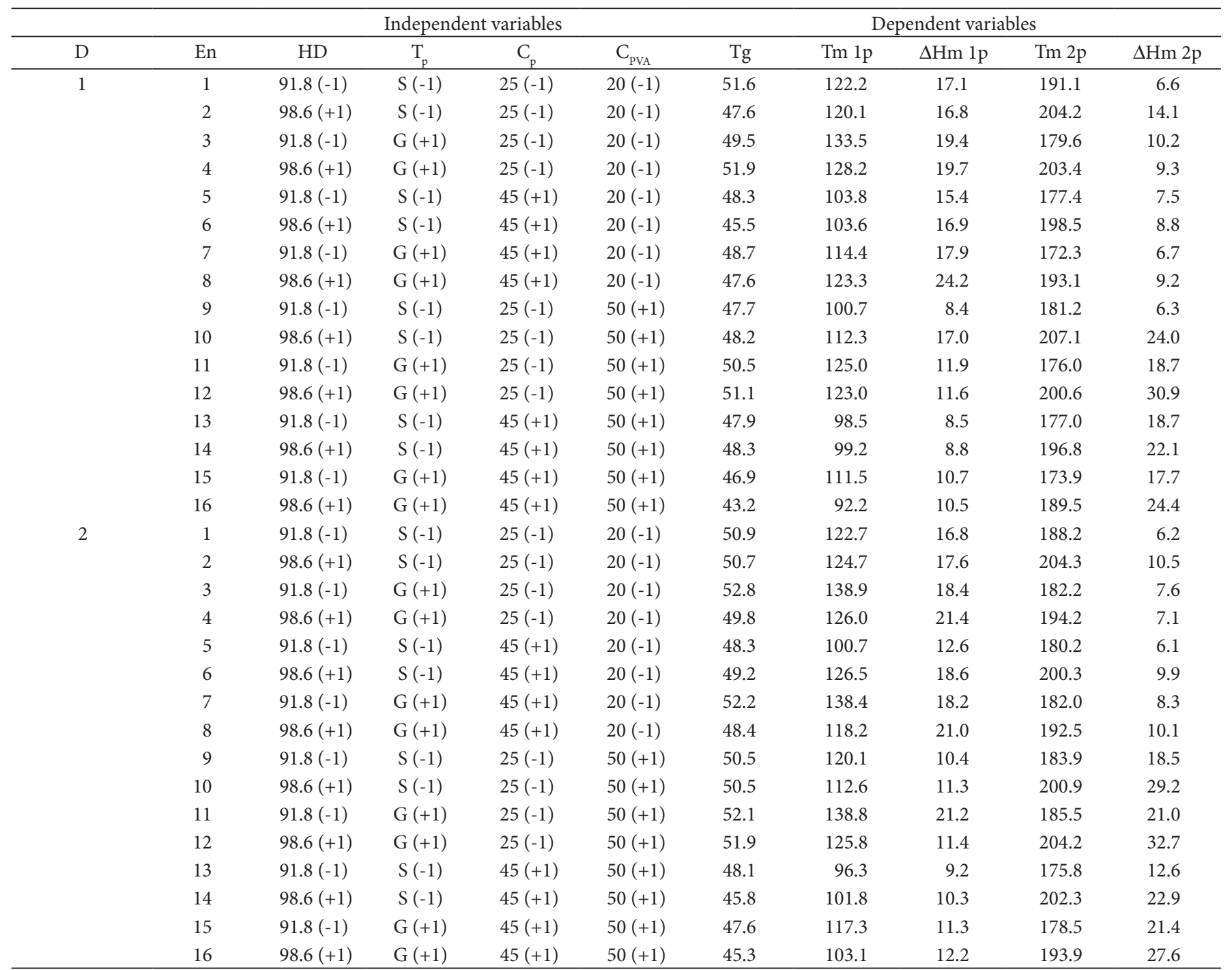

$\mathrm{D}=$ genuine duplicate of experimental design; $\mathrm{En}=$ essays; $\mathrm{HD}=$ hydrolysis degree of the PVA (\%); $\mathrm{T}_{\mathrm{p}}=$ plasticizer type: $\mathrm{G}=$ glycerol and $\mathrm{S}=$ sorbitol; $\mathrm{C}_{\mathrm{p}}=$ plasticizer concentration (g. $100 \mathrm{~g}^{-1}$ of macromolecules); $\mathrm{C}_{\mathrm{pVA}}=$ PVA concentration $\left(\mathrm{g} .100 \mathrm{~g}^{-1}\right.$ of macromolecules); $(-1$ and +1$)=$ coded values of variables; $\mathrm{Tg}=$ glass transition temperature $\left({ }^{\circ} \mathrm{C}\right)$; Tm $=$ melting temperature $\left({ }^{\circ} \mathrm{C}\right) ; \Delta \mathrm{Hm}=$ melting enthalpy $\left(\mathrm{J} \cdot \mathrm{g}^{-1}\right)$; and $1 \mathrm{p}$ and $2 \mathrm{p}=$ first and second peaks, respectively. 


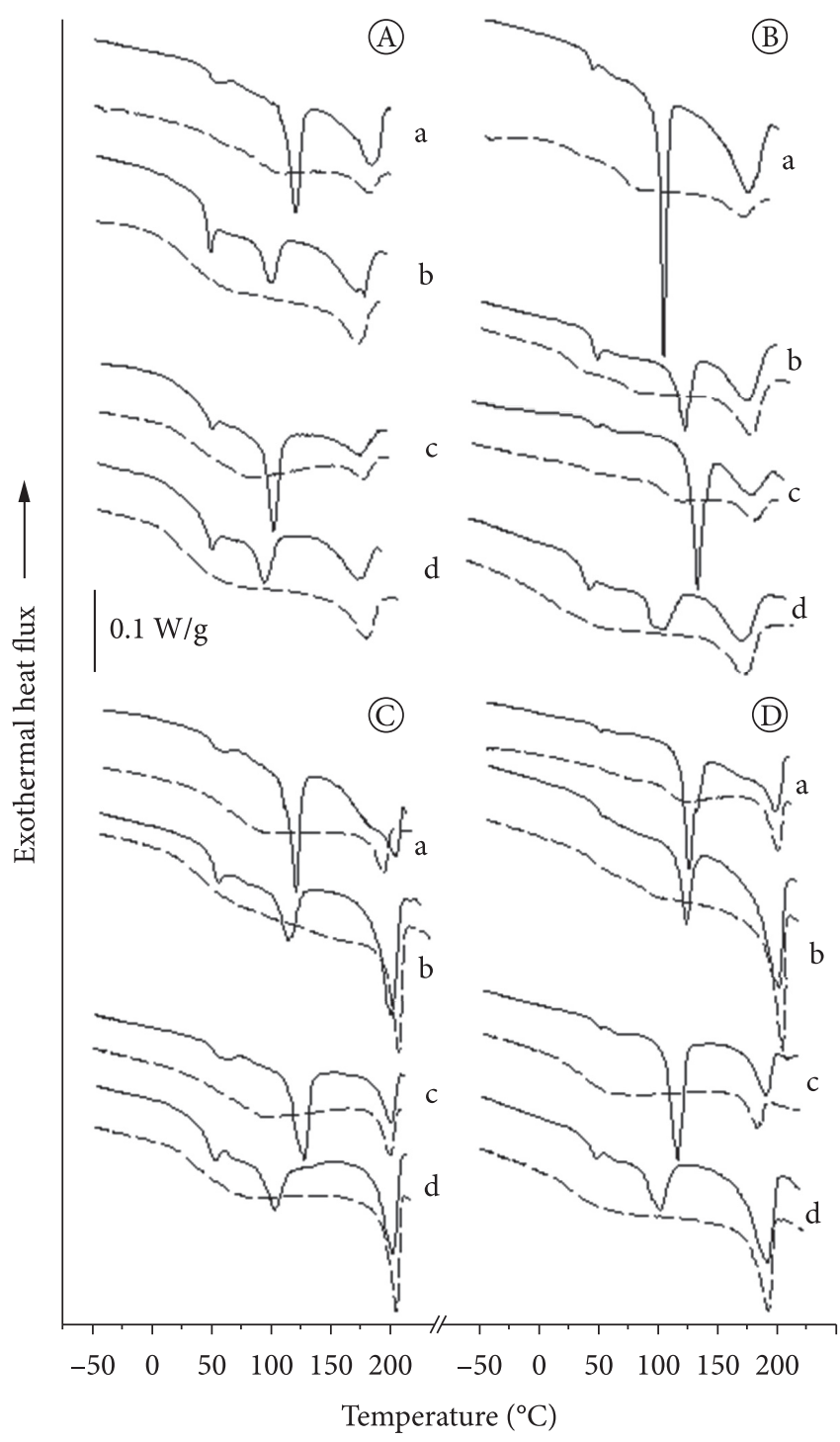

Figure 1. DSC curves of films based on blends of gelatin and PVA HD = 91.8\% ( $\mathrm{a}$ and b) or HD $=98.6 \%$ ( $\mathrm{c}$ and $\mathrm{d}$ ) and with sorbitol ( $\mathrm{a}$ and $\mathrm{c}$ ) or glycerol (b and d): a) 25\% plastizicer and 20\% PVA; b) 25\% plasticizer and 50\% PVA; c) $45 \%$ plasticizer and 20\% PVA; d) $45 \%$ plasticizer and 50\% PVA. --- 1st scan; --- 2nd scan.

temperatures $\left(172-207^{\circ} \mathrm{C}\right)$, must be associated to PVA crystals fusion. The identification of these fractions was based in results found in the literature: Vanin et al. (2005) found that the Tm of gelatin films with $10 \%$ of glycerol occurred around $125^{\circ} \mathrm{C}$, and Chiellini et al. $(2001 \mathrm{~b}, \mathrm{c})$ observed the Tm for pure PVA around $191{ }^{\circ} \mathrm{C}$. Also, Mendieta-Taboada et al. (2008) confirmed this phase separation by dynamic mechanical analysis for films based on gelatin/PVA with more than $10 \%$ of PVA in blends. Wang et al. (2007) observed phase separation between the PVA and a complex polysaccharide (carboxymethyl-chitosan) when this last component was in high content.

Curioulsy, the results of the second scan were also typical of partially crystalline materials, being observed also an endothermic peak after $\mathrm{Tg}$. In a general maner, it was observed that the $\mathrm{Tg}$ was displaced to lower values as compared to those of the first scan, as it could be expected (SOBRAL et al., 2001;
VANIN et al., 2005) (Table 2). Moreover, for some films, another $\mathrm{Tg}$ was also observed in higher temperatures $\left(>80^{\circ} \mathrm{C}\right)$. These results were tipical of systems where phase separations occurred (SOBRAL et al., 2001). According to Silva et al. (2008), these apparently strange behaviours bring the conjecture that the sample of PVA might be constituted of several fractions of different molecular weight.

Always concerning the second scan, the endothermal peak was observed between 163 and $209^{\circ} \mathrm{C}$ (Table 2), almost similar of those observed in the first scan (Table 1), corroborating with the suggestion that this phenomenon was associated to the PVA fraction. In a general manner, these behaviors were contrary to those observed for pure gelatin or films based on gelatin (SOBRAL; HABITANTE, 2001; SOBRAL et al., 2001; VANIN et al., 2005). According to these authors, with cryogenic cooling after the first scan, the microcrystalline interactions of the macromolecules did not have enough time to occur resulting in a completely amorphous material. Nevertheless, this behavior (Figure 1) was seen by other authors, such as Maria et al. (2008), who observed an endothermic peak in DSC curves of the second scan of films based on blends of gelatin and PVA, with and without plasticizer. The results obtained in the second scans confirm the indication that gelatin and PVA did not constitute a fully miscible system (SARTI; SCANDOLA, 1995).

\subsection{Surface-response analysis of phase properties}

The analysis of all DSC thermograms enabled the calculation of the experimental data shown in Tables 1 and 2, according to the experimental design described in those same tables. These data were submitted to statistical analysis, including the fitting of Equation 1, followed by analysis of variance at $95 \%$ confidence level (Table 3). Only statistically significant parameters were used to analyze the behavior, producing the respective equations, and consequently, to plot the response-surface presented later.

The linear model, due to its low regression coefficients values, does not have enough fit quality to represent the behavior of $\operatorname{Tg}\left(R^{2} \cong 0.4\right)$ and the first $\operatorname{Tm}\left(R^{2} \cong 0.3\right)$ obtained in the first scan (Table 3). But, the calculated model for the second melting temperature (Equation 2) was statistically significant and predictive (Table 3), allowing to plot some response-surface plots (Figure 2). According to Equation 2, neither the concentration of the PVA, nor the interactions between the independent variables affected the second Tm of films.

$\operatorname{Tm}(2 \mathrm{p}-1 \mathrm{st} \mathrm{scan})=189.7+9.4 \mathrm{HD}-2.1 \mathrm{~T}_{\mathrm{P}}-3.2 \mathrm{C}_{\mathrm{P}}$

These surface-response plots (Figure 2) confirm that the most important effect on the second Tm of the first scan was due to the hydrolysis degree of the PVA. This behavior agrees with that observed by Maria et al. (2008), which detected significant differences between the second Tm of the first scan, when comparing the films based on blends of gelatin and the PVA Celvol ${ }^{\circledR} 418$ or 350 .

On the other hand, the second Tm of the first scan of films plasticized with sorbitol were slightly higher than those of the films plasticized with glycerol, and the increase in Cp provoked an important reduction of that $\mathrm{Tm}$ as well. These behaviors were 
Table 2. Responses of thermal properties obtained from the second scan through differential scanning calorimetry.

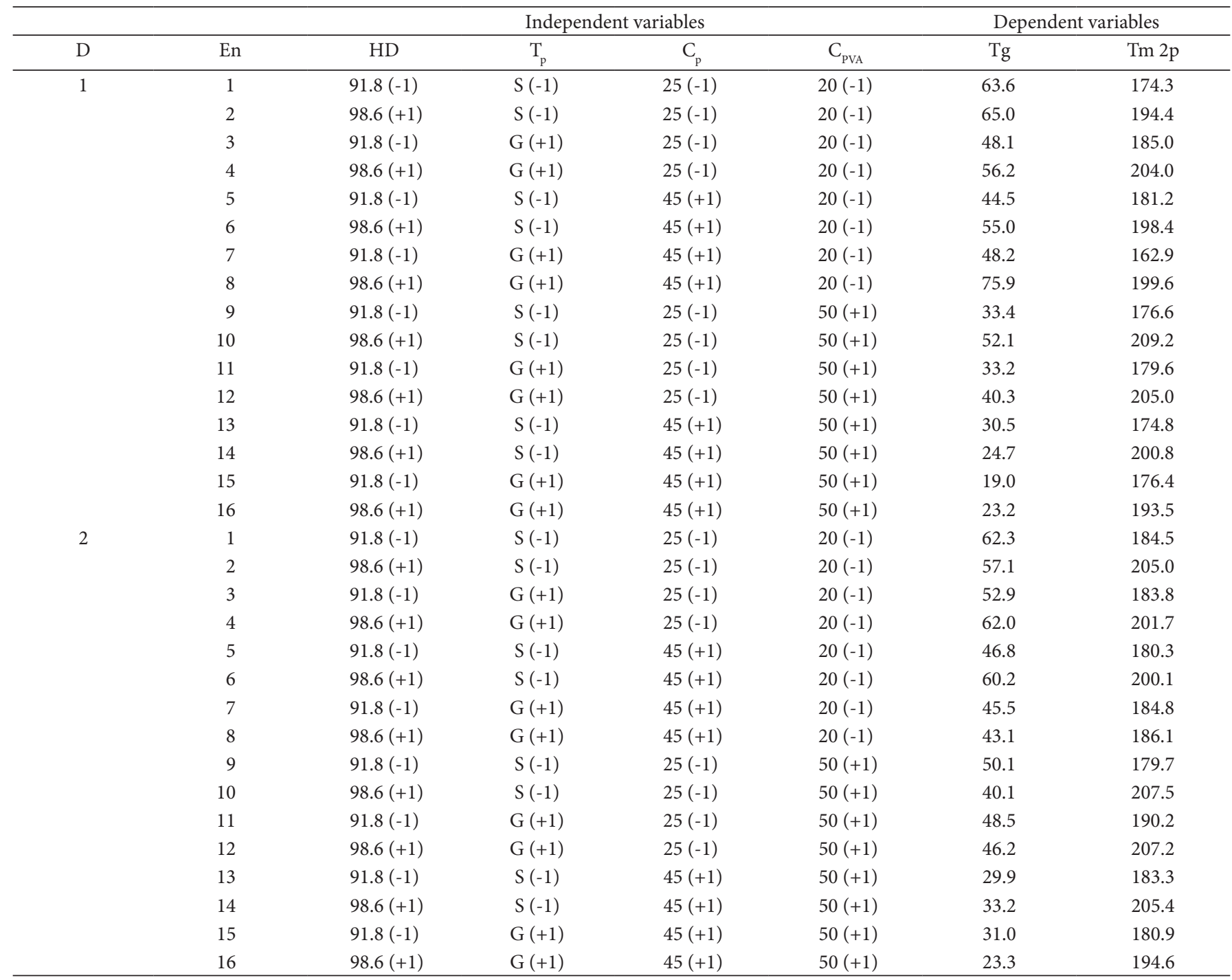

$\mathrm{D}=$ genuine duplicate of experimental design; $\mathrm{En}=$ essays; $\mathrm{HD}=$ hydrolysis degree of the PVA $(\%) ; \mathrm{T}_{\mathrm{p}}=$ plasticizer type: $\mathrm{G}=$ glycerol and $\mathrm{S}=$ sorbitol; $\mathrm{C}=$ plasticizer concentration (g.100 g ${ }^{-1}$ of macromolecules); $\mathrm{C}_{\mathrm{PVA}}=$ PVA concentration $\left(\mathrm{g} .100 \mathrm{~g}^{-1}\right.$ of macromolecules); $(-1$ and +1$)=$ coded values of variables; Tg $=$ glass transition temperature $\left({ }^{\circ} \mathrm{C}\right)$; Tm $=$ melting temperature $\left({ }^{\circ} \mathrm{C}\right)$ and $2 \mathrm{p}=$ second peak.

a consequence of the plasticization effect of sorbitol and glycerol (VANIN et al., 2005; THOMAZINE; CARVALHO; SOBRAL, 2005), where the glycerol had the stronger effect.

Concerning the Tg from the second scan (Equation 3), it was observed that the linear model can be fit to data; however, only two of the model parameters were statistically significant: $\mathrm{C}_{\mathrm{P}}$ and $\mathrm{C}_{\mathrm{PVA}}$, allowing to generate only one surface-response plot - considering that the fitted model was statistically significant and predictive (Table 3 ).

$\mathrm{Tg}=45.2-5.5 \mathrm{C}_{\mathrm{P}}-10.2 \mathrm{C}_{\mathrm{PVA}}$

As it can be observed in Figure 3, both the PVA and plasticizer concentrations had an important effect on that Tg. Also, Maria et al. (2008) did not observe the effect of the PVA type on the first Tg of the second scan, but these authors did not study the effect of the PVA concentration. But, on the other hand, the effect of the plasticizer concentration on the phase transitions like Tg could be expected, and it is well know in the films technology (SOBRAL et al., 2001; VANIN et al., 2005; THOMAZINE; CARVALHO; SOBRAL, 2005).

Concerning the second Tm of the second scan, the linear model can be fit to data, also with only two statistically significant parameters, namely the hydrolysis degree and the plasticizer concentration (Equation 4). Also, this model was statistically significant and predictive (Table 3 ), allowing to plot the surface-response curve as shown in Figure 4. The most important effect on the second Tm was provoked by the hydrolysis degree of the PVA, similarly to the observed in the first scan (Figure 2), because this phenomenon was associated to the PVA rich fraction, which was not affected by the thermal treatment $\left(90^{\circ} \mathrm{C}\right)$ of the filmogenic solution. A similar behavior was observed by Maria et al. (2008).

$\operatorname{Tm}(2 \mathrm{p}-2 \mathrm{nd}$ scan $)=190.3+10.4 \mathrm{HD}-2.6 \mathrm{C}_{\mathrm{P}}$ 

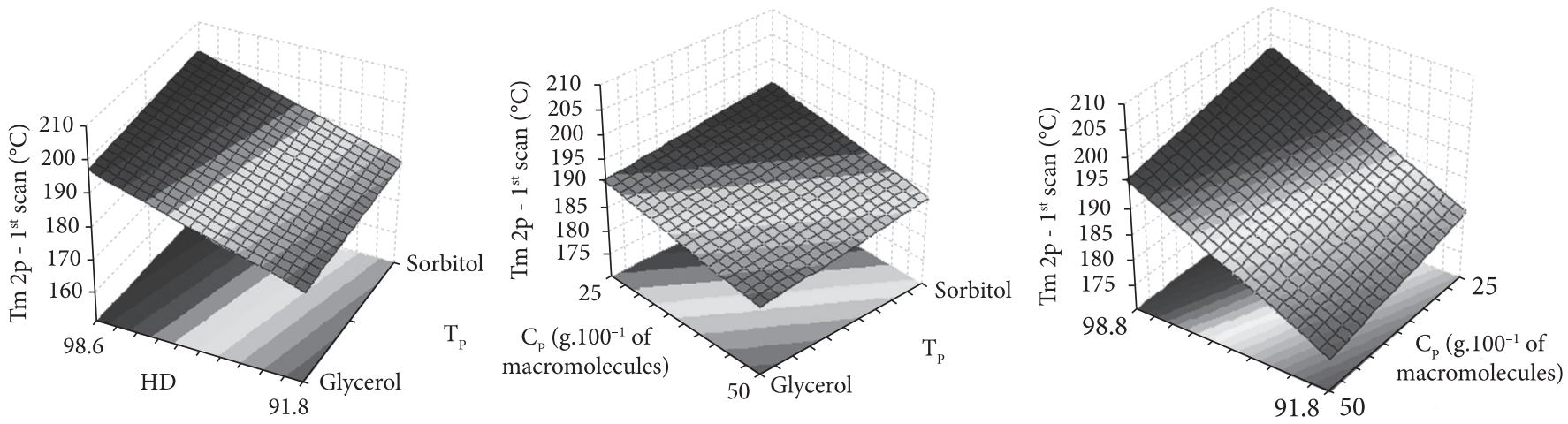

Figure 2. Response surfaces for the second melting temperature ( $\mathrm{Tm}$ ) obtained in the first scan.

Table 3. Results of analysis of variance (ANOVA) for termal properties ( $\mathrm{Tg}, \mathrm{Tm}, \Delta \mathrm{Hm}$ ) obtained from the first and second scan through differential scanning calorimetry.

\begin{tabular}{|c|c|c|c|c|c|c|c|}
\hline Response & Source & SS & $\mathrm{DF}$ & MS & $\mathrm{F}_{\mathrm{Cal}}$ & $\mathrm{F}_{\text {List }}$ & $\mathrm{R}^{2}$ \\
\hline $\mathrm{Tg}$ & Model & 66.12 & 1 & 66.12 & 20.53 & 4.17 & 0.4061 \\
\hline First scan & Residual & 96.70 & 30 & 3.22 & & & \\
\hline $\operatorname{Tm} 1 \mathrm{p}$ & Model & 1593.30 & 1 & 1593.30 & 12.50 & 4.17 & 0.2942 \\
\hline First scan & Residual & 3822.41 & 30 & 127.42 & & & \\
\hline $\operatorname{Tm} 2 p$ & Model & 3303.90 & 3 & 1101.3 & 94.13 & 2.95 & 0.9098 \\
\hline First scan & Residual & 327.62 & 28 & 11.70 & & & \\
\hline 1 st Tg & Model & 4336.00 & 2 & 2168.0 & 33.75 & 3.33 & 0.6995 \\
\hline Second scan & Residual & 1862.48 & 29 & 64.22 & & & \\
\hline $\operatorname{Tm} 2 \mathrm{p}$ & Model & 3713.96 & 2 & 1856.98 & 57.71 & 3.33 & 0.7992 \\
\hline Second scan & Residual & 933.23 & 29 & 32.18 & & & \\
\hline
\end{tabular}

$\mathrm{SS}=$ sum of squares; $\mathrm{DF}=$ degrees of freedom; MS = mean square; $\mathrm{F}_{\text {cal }}=\mathrm{F}_{\text {calculated }} ; \mathrm{F}_{\text {list }}=\mathrm{F}_{\text {listed }} ; \mathrm{R}^{2}=\mathrm{SS}_{\text {model }} / \mathrm{SS}$ residual $_{\text {Tg }}=$ glass transition temperature $\left({ }^{\circ} \mathrm{C}\right) ;$ Tm $=$ melting temperature $\left({ }^{\circ} \mathrm{C}\right)$; $\Delta \mathrm{Hm}=$ melting enthalpy $\left(\mathrm{J}_{\mathrm{g}} \mathrm{g}^{-1}\right)$; and $1 \mathrm{p}$ and $2 \mathrm{p}=$ first and second peaks, respectively.

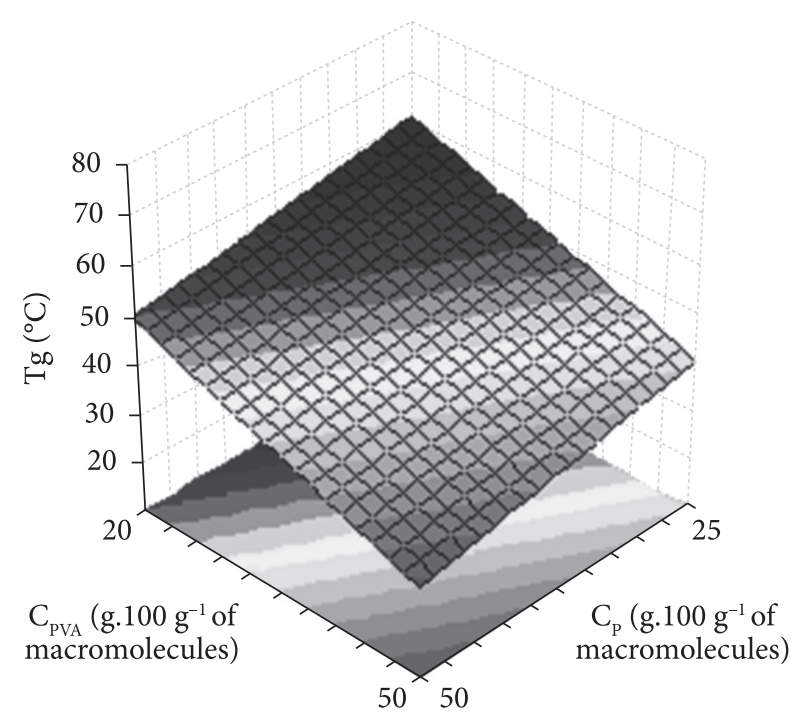

Figure 3. Response surfaces for the first glass transition temperature (Tg) obtained in the second scan.

It was observed that the hydrolysis degree of the PVA had the most important statistical effect on the melting of the crystals of the PVA rich fraction. Normally, the hydrolysis of
PVA is not necessarily completely achieved allowing different amounts of hydroxyl groups in the polymeric chain, meaning different hydrolysis degrees of PVA (MANSUR et al., 2008). Consequently, the potential of the PVA to interact with other polar polymers, such as gelatin, would be expected to vary as a function of its hydrolysis degree (PAL; BANTHIA; MAJUNDAR, 2006).

On the whole, the behaviors observed for the phase properties (Equations 2-4) were not necessarily similar to those observed on previous works with biodegradable films for some physical properties of the same type (CARVALHO et al., 2009). For example, neither the hydrolysis degree, nor the concentration of the PVA directly affected the puncture force, affecting only by means of the interaction terms, and the hydrolysis degree did not affect the puncture deformation of the films based on blends of gelatin and PVA. Moreover, the complete linear model was statistically significant to represent the behavior of the elongation at break data, but was not statistically significant for the tensile strength (CARVALHO et al., 2009). Nevertheless, Silva et al. (2008), working with similar biodegradable films, observed a direct relationship between $\mathrm{Tg}$, determined in the first scan, and the mechanical resistence of the respective films. 


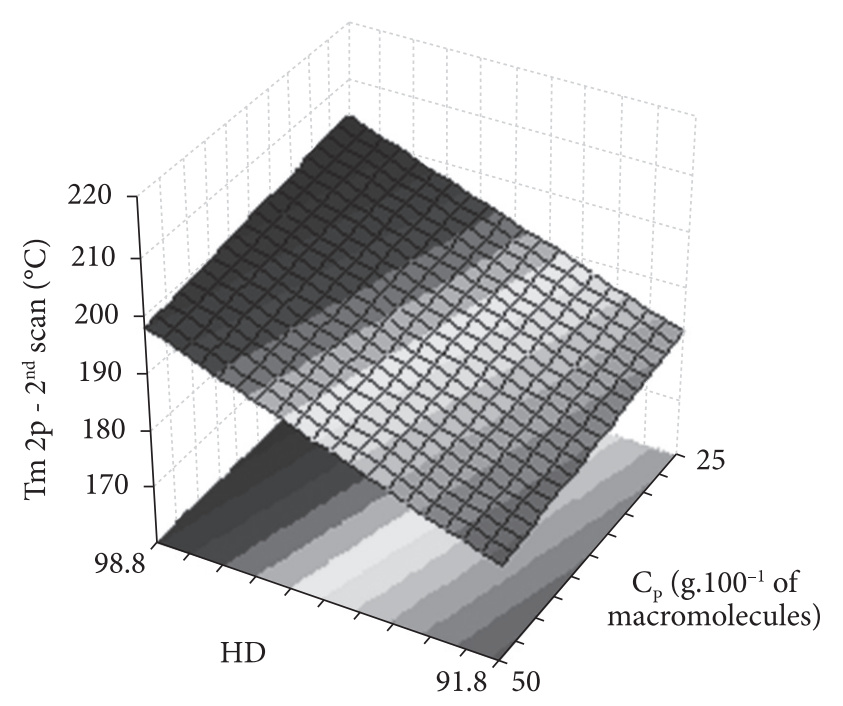

Figure 4. Response surfaces for the second melting temperature ( $\mathrm{Tm})$ obtained in the second scan.

\section{Conclusions}

The DSC thermograms obtained in both heating scans were typical of partially cristallin samples, where a glass transition ( Tg) was observed - related to the amorphous part of the material, followed by two endothermic peaks - related to the melting $(\mathrm{Tm})$ of the crystals.

For the data obtained on the first scan, the fitting of the linear model was statistically significant and predictive only for the second melting temperature. In this case, neither the concentration of the PVA, nor the interactions between the independent variables affected this property, where the most important effect on the second Tm of the first scan was due to the hydrolyses degree of the PVA.

In relation to the second scan, the linear model can be fit to $\mathrm{Tg}$ data with only two statistically significant parameters. Both the PVA and the plasticizer concentrations had an important effect on that Tg. Concerning the second $\mathrm{Tm}$ of the second scan, the linear model can be fit to the data, also with only two statistically significant parameters, namely the hydrolysis degree and the plasticizer concentration, where the most important effect was provoked by the hydrolysis degree of the PVA.

\section{Acknowledgements}

To FAPESP for the research grant (05/57781-8) and to CNPq for the PQI fellowship of PJAS.

\section{References}

ACHET, D. Ç.; HE, X. W. Determination of the renaturation level in gelatin films. Polymer, v. 36, n. 4, p. 787-791, 1995. http://dx.doi. org/10.1016/0032-3861(95)93109-y

ALEXY, P. et al. Poly (vinyl alcohol)-collagen hydrolysate thermoplastic blends: I Experimental design optimization and biodegradation behavior. Polymer Testing, v. 22, n. 7, p. 801-809, 2003. http://dx.doi.org/10.1016/s0142-9418(03)00016-3
ARVANITOYANNIS, I. S. Formation and properties of collagen and gelatin films and coatings. In: A. GENNADIOS, A. (Ed.) Proteinbased films and coatings. Boca Raton: CRC Press Lancaster EUA, 2002. p. 275-304.

ARVANITOYANNIS, I. et al. Edible films made from gelatin, soluble starch and polyols, Part 3. Food Chemistry, v. 60, n. 4, p. 593-604, 1997. http://dx.doi.org/10.1016/s0308-8146(97)00038-1

ARVANITOYANNIS, I.; NAKAYAMA, A.; AIBA, S. Edible films made from hydroxypropyl starch and gelatin and plasticized by polyols and water. Carbohydrate Polymers, v. 36, n. 2-3, p. 105-119, 1998 a. http://dx.doi.org/10.1016/S0144-8617(98)00017-4

ARVANITOYANNIS, I.; NAKAYAMA, A.; AIBA, S. Chitosan and gelatin based edible films: state diagrams, mechanical and permeation properties. Carbohydrate Polymers, v. 37, n. 4, p. 371-382, 1998 b. http://dx.doi.org/10.1016/S0144-8617(98)00083-6

BERGO, P. V. et al. Microwave Insertion Loss Measurements in GelatinBased Films. Measurement Science and Technology, v. 17, n. 12, p. 3261-3264, 2006. http://dx.doi.org/10.1088/0957-0233/17/12/010

BERGO, P.; SOBRAL, P. Effects of plasticizer on physical properties of pigskin gelatin films. Food Hydrocolloids, v. 21, n. 8, p. 1285-1289, 2007. http://dx.doi.org/10.1016/j.foodhyd.2006.09.014

CAO, N; FU, Y.; HE, J. Mechanical properties of gelatin films cross-linked, respectively, by ferulic acid and tannin acid. Food Hydrocolloids, v. 21, n. 4, p. 575-584, 2007. http://dx.doi. org/10.1016/j.foodhyd.2006.07.001

CARVALHO, R. A.; GROSSO; C. R. F. Characterization of gelatin based films modified with transglutaminase, glyoxal and formaldehyde. Food Hydrocolloids, v. 18, n. 5, p. 717-726, 2004. http://dx.doi. org/10.1016/j.foodhyd.2003.10.005

CARVALHO, R. A. et al. Study of some physical properties of biodegradable films based on blends of gelatin and poly (vinyl alcohol) using a response-surface methodology. Materials Science \& Engineering C, v. 29, n. 2, p. 485-491, 2009. http://dx.doi. org/10.1016/j.msec.2008.08.030

CHIELLINI, E. et al. Composite films based on biorelated agroindustrial waste and poly (vinyl alcohol). Preparation and mechanical properties characterization. Biomacromolecules, v. 2, n. 3, p. 1029-1037, 2001a. PMid:11710006. http://dx.doi. org/10.1021/bm010084j

CHIELLINI, E. et al. Gelatin-based blends and composites. Morphological and thermal mechanical characterization. Biomacromolecules, v. 2, n. 3, p. 806-811, 2001b. PMid:11710035. http://dx.doi.org/10.1021/bm015519h

CHIELLINI, E. et al. Composite films based on waste gelatin: thermal-mechanical properties and biodegradation testing. Polymer Degradation and Stability, v. 73, n. 3, p. 549-555, $2001 \mathrm{c}$. http://dx.doi.org/10.1016/S0141-3910(01)00132-X

DAVANÇO, T.; TANADA-PALMU, P.; GROSSO, C. Filmes compostos de gelatina, triacetina, ácido esteárico ou capróico: efeito do $\mathrm{pH}$ e da adição de surfactantes sobre a funcionalidade dos filmes. Ciência e Tecnologia de Alimentos, v. 27, n. 2, p. 408-416, 2007. http://dx.doi.org/10.1590/S0101-20612007000200034

DICHARRY, R. N. et al. Wheat gluten-thiolated poly (vinyl alcohol) blends with improved mechanical properties. Biomacromolecules, v. 7 , n. 10, p. 2837-2844, 2006. PMid:17025360. http://dx.doi. org/10.1021/bm060432n

LIM, L. T.; MINE, Y.; TUNG, A. Barrier and tensile properties of transglutaminase cross-linked gelatin films as affect by relative humidity, temperature, and glicerol content. Journal 
of Food Science, v. 64, n. 4, p. 616-622, 1999. http://dx.doi. org/10.1111/j.1365-2621.1999.tb15096.x

MANSUR, H. S. et al. FTIR spectroscopy characterization of poly (vinyl alcohol) hydrogel with different hydrolysis degree and chemically crosslinked with glutaraldehyde. Materials Science and Engineering C, v. 28, n. 4, p. 539-548, 2008. http://dx.doi. org/10.1016/j.msec.2007.10.088

MARIA, T. M. C. et al. The effect of the degree of hydrolysis of the PVA and the plasticizer concentration on the color, opacity, and thermal and mechanical properties of films based on PVA and gelatin blends. Journal of Food Engineering, v. 87, n. 2, p. 191-199, 2008.

MATSUMURA, S. et al. Novel poly (vinyl alcool) degrading enzyme and the degradation mechanism. Macromolecules, v. 32, n. 23, p. 7753-7761, 1999. http://dx.doi.org/10.1021/ma990727b

MENDIETA-TABOADA, O. W. M. et al. Thermomechanical properties of biodegradable films based on blends of gelatin and poly (vinyl alcohol). Food Hydrocolloids, v. 22, n. 8, p. 1485-1492, 2008. http://dx.doi.org/10.1016/j.foodhyd.2007.10.001

MENEGALLI, F. C. et al. Characteristics of gelatin biofilms in relation to drying process conditions near melting. Drying Technology, v. 17, n. 7-8, p. 1697-1706, 1999. http://dx.doi. org/10.1080/07373939908917646

MORAES, I. C. F. et al. Influência do grau de hidrólise do poli (vinil álcool) nas propriedades físicas de filmes à base de blendas de gelatina e poli (vinil álcool) plastificados com glicerol. Ciência e Tecnologia de Alimentos, v. 28, n. 3, p. 738-745, 2008. http://dx.doi.org/10.1590/S0101-20612008000300034

PAL, K.; BANTHIA, K.; MAJUNDAR, D. K. Polyvinyl Alcohol-gelatin patches of salicylic acid: preparation characterization and drug release studies. Journal of Biomaterials Applications, v. 21, n. 1, p. 75-91, 2006. PMid:16443632. http://dx.doi. org/10.1177/0885328206056312

PRANOTO, Y.; LEE, C. M.; PARK, H. J. Characterizations of fish gelatin films added with gellan and k-carrageenan. LebensmittelWissenschaft und-Technologie, v. 40, n. 5, p. 766-774, 2007.

ROQUES, M. A. From drying to thermo-hydro-rheology - A thirtyyear-long unfinished maze. Drying Technology, v. 26, p. 1172-1179, 2008. http://dx.doi.org/10.1080/07373930802306946

ROSS; Y.; KAREL, M. Plasticizing effet of water on thermal behavior and crystallization of amorphous food models. Journal of Food Science, v. 56, n. 1, p. 38-43, 1991. http://dx.doi. org/10.1111/j.1365-2621.1991.tb07970.x

SARTI, B.; SCANDOLA, M. Viscoelastic and thermal-properties of collagen poly (vinyl alcohol) blends. Biomaterials, v. 16, n. 10, p. 785-792, 1995. http://dx.doi.org/10.1016/0142-9612(95)99641-X

SLADE, L.; LEVINE, H. Beyond water activity: recent advances base don na alternative approach to the assessment of food quality and safety. Critical reviews in Food Science and Nutrition, v. 30, p. 115-360, 1991. PMid:1854434. http://dx.doi. org/10.1080/10408399109527543
SILVA, G. G. D. et al. Biodegradable films based on blends of gelatin and poly (vinyl alcohol): effect of PVA type or concentration on some physical properties of films. Journal of Polymers and the Environment, v. 16, n. 4, p. 276-285, 2008. http://dx.doi. org/10.1007/s10924-008-0112-9

SOBRAL, P. J. A. Propriedades funcionais de biofilmes de gelatina em função da espessura. Ciência \& Engenharia, v. 8, n. 1, p. 60-67, 1999.

SOBRAL, P. J. A.; HABITANTE, A. M. Q. B. Phase transitions of pigskin gelatin. Food Hydrocolloids, v. 15, n. 4-6, p. 377-82, 2001. http://dx.doi.org/10.1016/S0268-005X(01)00060-1

SOBRAL, P. J. A. et al. Mechanical, water vapor barrier and thermal properties of gelatin based edible films. Food Hydrocolloids, v. 15 , n. $4-6$, p. $423-432$, 2001. http://dx.doi.org/10.1016/S0268005X(01)00061-3

SOBRAL, P. J. A.; MONTERREY-QUINTERO, E. S.; HABITANTE, A. M. Q. B. Glass transition of Nile tilapia myofibrillar protein films plasticized by glycerin and water. Journal of Thermal Analysis and Calorimetry, v. 67, n. 2, p. 499-504, 2002. http://dx.doi. org/10.1023/A:1013905400900

THARANATHAN, R. N. Biodegradable films and composite coatings: past, present and future. Trends in Food Science \& Technology, v. 14, n. 3, p. 71-78, 2003. PMid:21299575. http://dx.doi.org/10.1016/ S0924-2244(02)00280-7

THOMAZINE; M.; CARVAlHO, R. A.; SOBRAL, P. J. A. Physical Properties of Gelatin Films Plasticized by Blends of Glycerol and Sorbitol. Journal of Food Science, v. 70, n. 3, p. 172-176, 2005.

WANG, L-C. et al. Controlled drug release through carboxymethylchitosan/poly (vinyl alcohol) blend films. Polymer Engineering and Science, v. 47, n. 9, p. 1373-1379, 2007. http://dx.doi.org/10.1002/pen.20823

Van de VELDE, K.; KIEKENS, P. Biopolymers: overview of several properties and consequences on their applications. Polymer Testing, v. 21, n. 4, p. 433-442, 2002. http://dx.doi.org/10.1016/ S0142-9418(01)00107-6

VANIN, F. M. et al. Effects of plasticizers and their concentrations on thermal and functional properties of gelatin based films. Food Hydrocolloids, v. 19, n. 5, p. 899-907, 2005. http://dx.doi. org/10.1016/j.foodhyd.2004.12.003

XIAO, C. et al. Characterization of poly (vinyl alcohol)-konjac glucomannan blend films. Journal of macromolecular science Part A. Pure Applied Chemistry, v. 34A, n. 9, p. 1009-1021, 2000. http://dx.doi.org/10.1081/MA-100101137

YAKIMETS, I. et al. Mechanical properties with respect to water content of gelatin films in glassy state. Polymer, v. 46, n. 26, p. 12577-12585, 2005. http://dx.doi.org/10.1016/j.polymer.2005.10.090

ZIEGLER, C. R.; FOEGEDING, E. A. The gelation of Proteins. Advances in Food and Nutrition Research, v. 34, p. 203-298, 1990. http://dx.doi.org/10.1016/S1043-4526(08)60008-XTable 1. Responses of thermal properties obtained from the first scan by differential scanning calorimetry. 